\title{
sciendo
}

CIVIL AND ENVIRONMENTAL ENGINEERING REPORTS

E-ISSN 2450-8594

CEER 2021; 31 (2): 0293-0309

DOI: $10.2478 /$ ceer-2021-0030

Original Research Article

\section{APPLICATION OF TERRESTRIAL LASER SCANNING FOR THE INVENTORY OF HISTORICAL BUILDINGS ON THE EXAMPLE OF MEASURING THE ELEVATIONS OF THE BUILDINGS IN THE OLD MARKET SQUARE IN JAROSŁAW}

\author{
Anna Gardzińska ${ }^{1}$ \\ Rzeszow University of Technology, Rzeszów, Poland
}

\begin{abstract}
Terrestrial laser scanning (TLS) technology is increasingly used in surveying, construction and architecture. The potential of the data obtained by this method creates the possibility of its versatile application also in conservation and revitalization of monuments, archaeology or history. The use of this technology during the creation of architectural documentation of a historic building greatly facilitates the acquisition of comprehensive information about its actual condition in a fast, non-invasive and very precise manner. Thanks to digital technology, it also creates the possibility to accurately interpret the condition of an object and present its model in a virtual space. This technology provides the ability to transfer acquired image elements with high accuracy of their mapping to plans and designs prepared by architects and contractors. It is also possible to maintain high technical standards in the processes aimed at the preparation of the required graphical studies, thanks to the use of the point cloud obtained in TLS. One of the most important advantages of using this measurement method is the possibility of combining it with data from e. g. from photogrammetric tools, which gives the possibility to fill in the missing elements creating a more complete picture of the needed data. This paper presents the implementation of terrestrial laser scanning technology as a non-invasive method for the modelling of walls and buildings of the so-called "greenfield". Revers BIM on the example

\footnotetext{
${ }^{1}$ Corresponding author: Rzeszow University of Technology, Rzeszów, Poland, e-mail: a.gardzinska@prz.edu.pl
} 
of the measurement of the facades of the buildings of the old market in Jarosław. This technology allows for preparation of precise architectural documentation including: projections, sections, elevation views, 3D models or multimedia visualizations. The use of TLS for cultural heritage research also enables the preparation of fully complete documentation for conservation and restoration works aimed at maintaining the current state of monuments or even at reconstructing their damaged architectural elements.

Keywords: laser scanning technology, modelling methods, architectural documentation, $3 \mathrm{D}$ visualization, cultural heritage

\section{INTRODUCTION}

The processes of social and cultural transformations have undergone numerous and profound changes in recent decades, making it more and more common nowadays to notice and emphasize the role of the cultural factor. This situation is distinguished in the position of the Polish National Commission for UNESCO, which emphasizes that ". . . in the XXI century the fundamental, although still developing and emerging element of culture, which is the essence of sustainable development, has gained importance. A sine qua non for the full realisation of the concept of sustainable development is its implementation in all societies. On the other hand, culture can be both the goal and the subject of development, as well as the means to achieve it, and the conditioning and directing of development generated by particular causal factors" $[11,38]$.

In each city, historic tenement houses performed and still perform various functions, which were and still are conditioned by their size, location and the provisions of the location plans. Depending on the need, over the centuries, their solids underwent various modifications [31,32]. Many of the small towns, like Jarosław, showed a tendency to succumb to crises, which projected, and still projects today, a decline in their physiognomy and social deprivation [16, 4]. As a result, it became necessary to find new solutions to highlight the potential of monuments being an opportunity to improve the living conditions of the local community in accordance with the principles of sustainable development [7]. It should also be noted the change in the approach to the perception and reception of culture, to its importance in the process of sustainable development, to which the enormous technological progress has undoubtedly contributed. Modern technology has radically changed the way we create and communicate the information necessary to create inventory and design documentation. The most significant thing about these advanced technological methods has become that they enable non-invasive examination of the condition of each building and the use of innovative technological and material solutions [33, 34, 25, 20, 21, 35, 19]. Historic buildings are also often characterized by complex geometry, many elements of small architecture, ornaments or decorations, which results in the need 


\author{
APPLICATION OF TERRESTRIAL LASER SCANNING FOR THE INVENTORY \\ OF HISTORICAL BUILDINGS ON THE EXAMPLE OF MEASURING THE ELEVATIONS \\ OF THE BUILDINGS IN THE OLD MARKET SQUARE IN JAROSŁAW
}

for a thorough and comprehensive data acquisition technology, for which TLS can be best used. Terrestrial Laser Scanning). This technology provides the ability to transfer acquired image elements with high accuracy of their mapping onto prepared plans and designs by architects and contractors. It is also possible, through the use of the point cloud acquired in TLS, to maintain high technical standards in the processes aimed at preparing the needed graphical studies [40]. One of the most important advantages of using TLS is that it can be combined with data from e. g. from photogrammetric tools, which gives the possibility to fill in the missing elements creating a more complete picture of the needed data. This ultimately allows for more accurate analysis of control elements and geospatial data [6]. The integration of this data allows a new "thematic layer" to be created in the 3D model for the structures that make up the historic site. Thanks to that it is possible to prepare images for such elements as polychrome or roofing, as well as graphically expose construction elements such as brick, stone or wood. This is used when preparing a 3D model to complete its base solid with these elements and give it the characteristics of a real object. Models of this type prepared thanks to TLS technology are nowadays the most commonly used for the presentation and revaluation of historic buildings and even entire heritage areas $[39,27,28,1,23,9,2]$.

The aim of this paper is to implement the technology of terrestrial laser scanning as a non-invasive method for modelling walls and buildings of the so called "greenfield". Revers BIM on the example of the measurement of the facades of the buildings of the old market in Jarosław. Faro 3D scanner (photo 1), Nikon D750 and Autodesk Recap 360 software were used to model the elevation of the Old Market Square in Jarosław. 


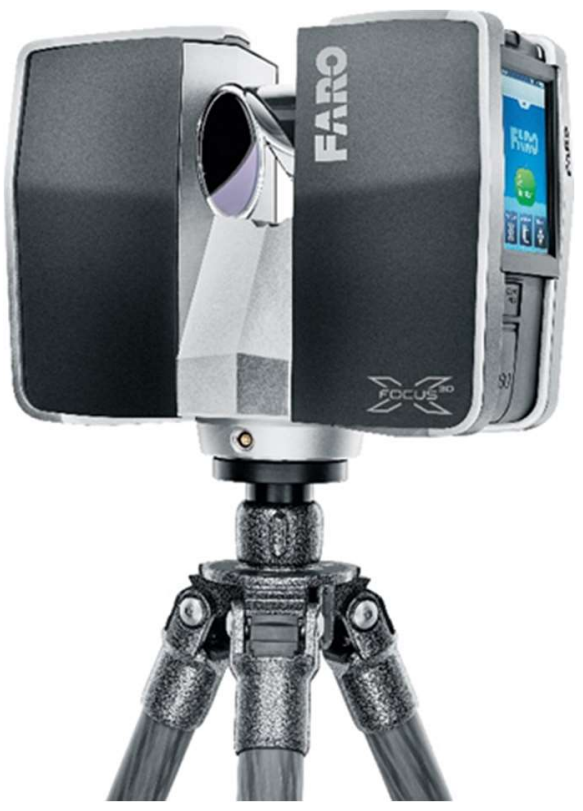

Photo. 1. Laser scanner FARO Focus 3D;

Source: https://www.logismarket.pl/faro-technologies-polska/skaner-laserowy3d/3706207826-p.html

The TLS method is increasingly used in building and architecture due to the speed, ease and accuracy of the measurement data obtained. Registered image of the studied object in the form of a point cloud is an excellent source of data for complex analysis and research of any fragment or the whole object, in this case the facade. This technology allows for preparation of precise architectural documentation including: projections, sections, elevation views, 3D models or multimedia visualisations $[22,8,17]$. The use of TLS for cultural heritage research makes it possible to prepare fully complete documentation for conservation and restoration works aimed at maintaining the current state of monuments or even at reconstructing their damaged architectural elements.

\section{THE TLS METHOD}

In order to obtain comprehensive knowledge about a given cultural heritage monument, it is necessary to acquire as much data as possible, which is used in later technical descriptions or cartographic research and visualization. Until recently, this was done using, among other things from surveying tools, direct height measurement method - tachometry or short-range photogrammetry. Currently, due to the reduction of measurement time and increased accuracy 


\section{APPLICATION OF TERRESTRIAL LASER SCANNING FOR THE INVENTORY OF HISTORICAL BUILDINGS ON THE EXAMPLE OF MEASURING THE ELEVATIONS OF THE BUILDINGS IN THE OLD MARKET SQUARE IN JAROSŁAW}

achieved, it is increasingly replaced by the laser scanning method. Nevertheless, it took almost 25 years to implement this technology to perform cultural heritage documentation before it became a popular tool used in this field. This was due to both the reluctance of the historic architecture or archaeology communities to embrace new technologies and the lack of widespread access to teaching classes related to 3D software at universities [30, 10, 18]. For example, in Poland, this type of technology has been approved for the performance of geodetic situational and height measurements only at the beginning of the twenty-first century. The data obtained from laser scanning can be used not only to develop basic technical documentation of the monument, but also to carry out various types of surveys of buildings and assess the condition of the measured object $[8,5,29,3,26]$. Historic buildings are always characterized by their specificity and require individual approach to the works carried out on them. They require careful examination of the resulting deformations and movement of structural elements.

The advantage of TLS technology is the ability to build a model of the construction object and carry out a quick check of the compliance of the work performed with the design, which during its implementation reduces the risk of errors in execution and eliminates errors associated with the failure to meet design errors. This is especially important when carrying out work that requires a high degree of accuracy. Laser scanning is a non-contact method of imaging the surface of the tested object, using electromagnetic radiation emitted and received by the scanner. Depending on the needs and conditions in which the measurements are performed, the equipment has a choice of daylight scanning (outside the object) or artificial light (inside the object). The scanning process is carried out with a user-defined density, realized by rotating the scanner with a specified vertical and horizontal angle around its own axis and is based on measuring the distance of the point from the device and the direction of the laser beam. The resulting data set, in the form of a point cloud, reaches a size of several million points with known coordinates in any coordinate system X, Y, Z, which is incomparably superior to traditional measurement methods. In addition, a point cloud describing the geometry of an object can be overlaid with a texture derived from images taken with a digital camera embedded in the scanner, to facilitate the interpretation of structural or material details $[12,42,14]$. These devices also offer a choice of predefined operating modes or full configuration of scanning parameters. When fully configuring the scanner, please note that you can change the time of a single measurement, this will depend on the settings selected. The best quality and highest resolution scans can take over 1 hour to complete. 
In the work with terrestrial laser scanning, we can conventionally distinguish 4 stages:

- deployment of measuring stations,

- execution of measurements using a laser beam,

- acquisition of a single point cloud from single scans for the whole object,

- processing of acquired data.

\section{TLS MEASUREMENT ON THE EXAMPLE OF THE TENEMENT HOUSES OF THE OLD MARKET SQUARE IN JAROSŁAW}

The TLS measurement starts with the proper arrangement of the measurement stands by means of reference spheres, which are set up at appropriate distances in the area of the performed measurement. Balls with a diameter of $140 \mathrm{~mm}$ are fixed to the ground by a magnet or metal feet. This is a key step, because good positioning of the stations determines the accuracy of the measurement, which is related to the angle of incidence of the beam and the distance from the object. For example, for larger beam angles (of the order of $30-40^{\circ}$ ), especially for dark surfaces (roofing), the number of registered points decreases several times. Prior to the measurement, in addition to the arrangement of the measurement stations, the location of the adjustment points should be planned [13, 12, 41].

The next step is for the device to take a measurement and collect data using a laser beam released from the scanner, which after bouncing off a given object surface returns back to the detector. In addition to the coordinates $(\mathrm{X}, \mathrm{Y}, \mathrm{Z})$, the device also records the strength of the returning signal. The value of its intensity is determined in the form of RGB components or gray scale, where blue color indicates strong reflection, and red color - low albedo (ratio of reflected to incident radiation) $[43,14]$. The intensity of these parameters is closely related to the angle of incidence of the laser beam on the scanned surface. As the angle of incidence of the beam increases, the strength of the signal returning to the device decreases. The most favorable scanning results are achieved when the beam is close to perpendicular to the surface under examination. The colour of the object being scanned is also a factor, with light colours and grey surface tones giving the most effective measurements, while black and red have poor signal return. This collects information about the time it took the beam to travel a certain distance back and forth and about both vertical and horizontal angles of the object relative to the scanner $[3,36]$.

The laser beam reflection intensity, and thus the range and efficiency of the measurements, can also be affected by the structure of the test object. This is due to the differences in reflectivity and surface scattering of different building materials, so the type of material of which the object is made plays no small role 


\section{APPLICATION OF TERRESTRIAL LASER SCANNING FOR THE INVENTORY OF HISTORICAL BUILDINGS ON THE EXAMPLE OF MEASURING THE ELEVATIONS \\ OF THE BUILDINGS IN THE OLD MARKET SQUARE IN JAROSEAW}

in the measurements. The biggest difficulties were observed in measurements of glass objects and chromium surfaces due to their ability to perpendicularly reflect the laser beam and scattering properties. The scanning of concrete and brick structures sometimes requires that the distance between the scanner and the object be reduced and more stations be spread out. The best materials, with the most favourable properties, are wood, PVC and slightly rough surfaces [15]. In the case of the buildings in Jaros ${ }^{3} \mathrm{aw}$, due to their brick construction and the revitalization of the Market Square, the scanner was placed at a distance of approx. $6-7 \mathrm{~m}$. The next step was to merge the data obtained from the scans into one point cloud for the whole object (photo 2, photo 3).

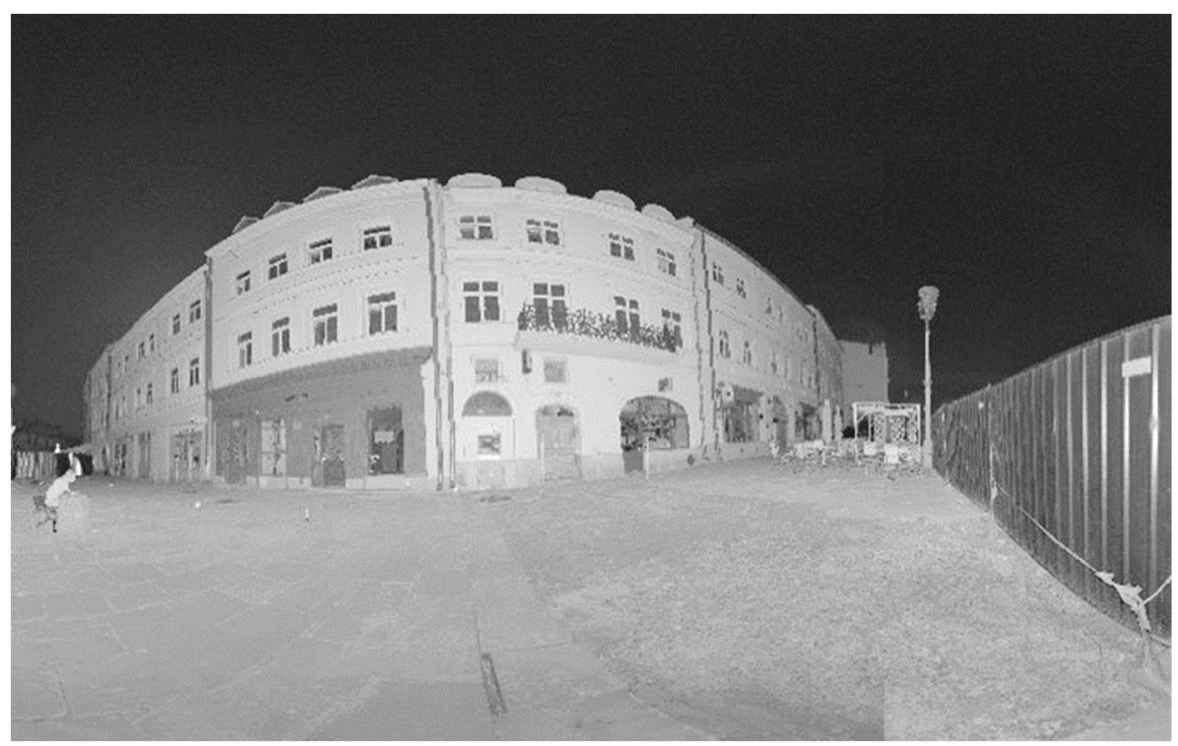

Photo 2. Single-scan point cloud in planar view mode, southeast frontage view; Source: own elaboration 


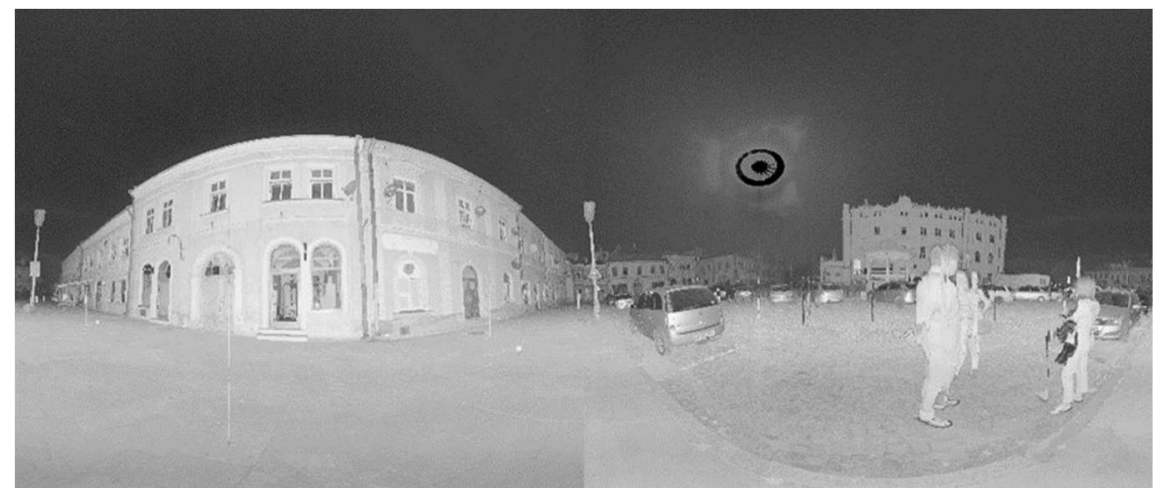

Photo 3. Single-scan point cloud in planar view mode, north-western frontage view; Source: own elaboration

There are several methods for combining data obtained from laser scanner measurements. The first is to indicate planes, situational details or solids. The second method, which is more accurate, involves the use of signalled adjustment points, or reference spheres, which increase the accuracy of this method over the others. This is related to their spherical shape, thanks to which they can be recorded from different sides and directions [37].

The final stage of work related to the course of development of the acquired data can be conventionally divided into three sub-stages. The first one is the preprocessing of the observation results, which is usually carried out already during the measurement of the so called "measurement of the observation" eliminating fat errors. It is mainly based on the so-called cleaning of the drawing by elimination of the measurement points which, due to the adopted spatial criteria, did not meet the measurement conditions. The second sub-stage, treated as a fundamental one, is characterised by the selection of points representing objects or their fragments extracted from the set of results obtained from all the measurements of the connected stations. The selection made is mainly due to the spatial conditions of the object under study. In the final sub-step of point cloud processing, the created objects are transformed into the appropriate format, provided by the target spatial information system, which has modules enabling point cloud processing and proper data set processing (most CAD systems) [12]. In the presented example, to model facades of the buildings in the Old Market Square in Jarosław, obtained point cloud was transported to the Autodesk Recap 360 software. This program allowed us to process the point cloud, measure distances, dimensions (photo. 4), and also made it possible to create a preview image of the facade in the form of orthophoto image, which is an additional result of scanning (photo. 5, photo. 6). 
APPLICATION OF TERRESTRIAL LASER SCANNING FOR THE INVENTORY OF HISTORICAL BUILDINGS ON THE EXAMPLE OF MEASURING THE ELEVATIONS OF THE BUILDINGS IN THE OLD MARKET SQUARE IN JAROSŁAW

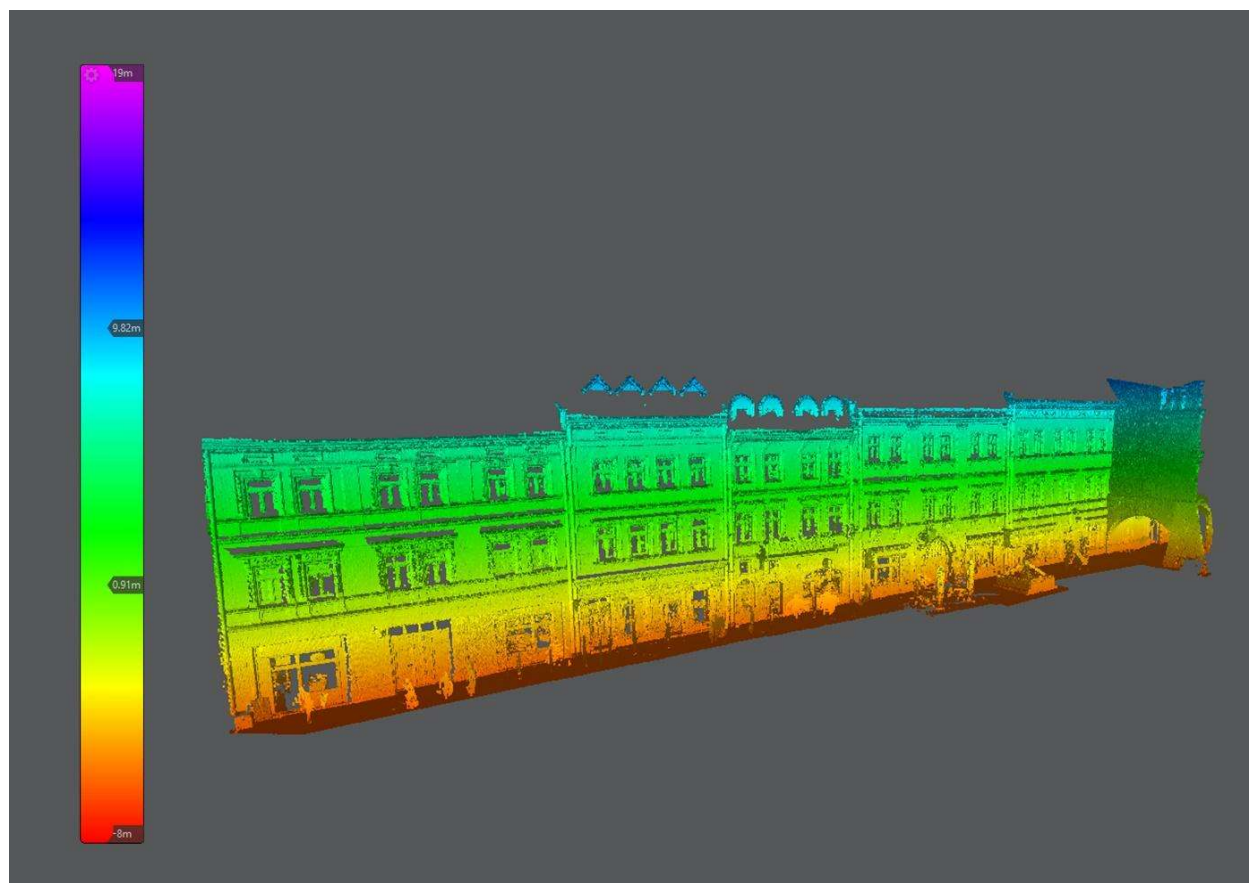

Photo 4. An example of the obtained illustrative data concerning the height of the examined market frontage;

Source: own elaboration

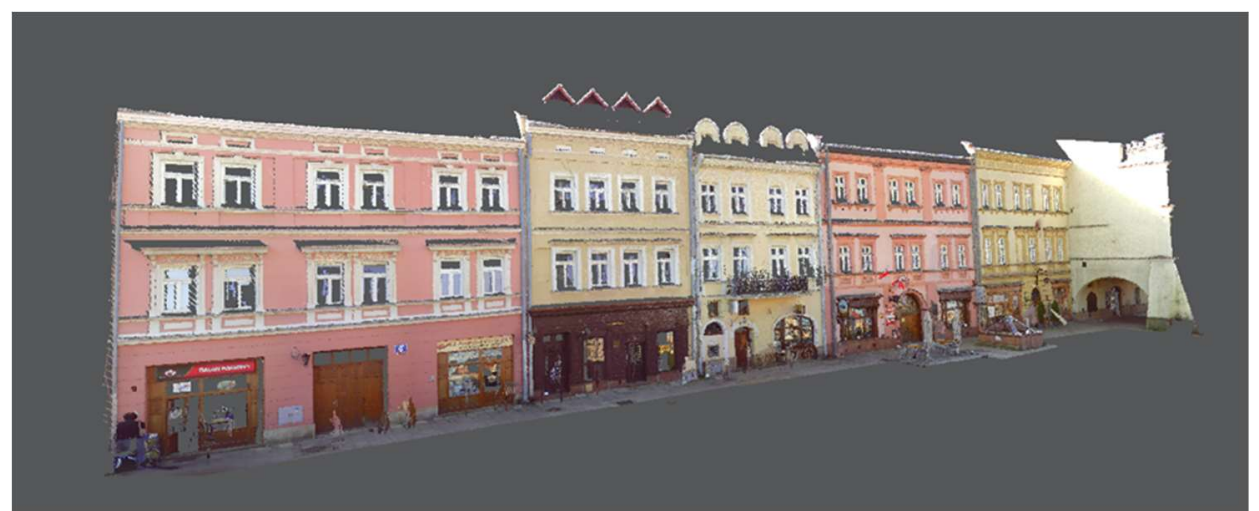

Photo 5. An example of a generated orthophoto image of the south-eastern frontage of the Old Market in Jarosław in Autodesk Recap 360 program;

Source: own elaboration 


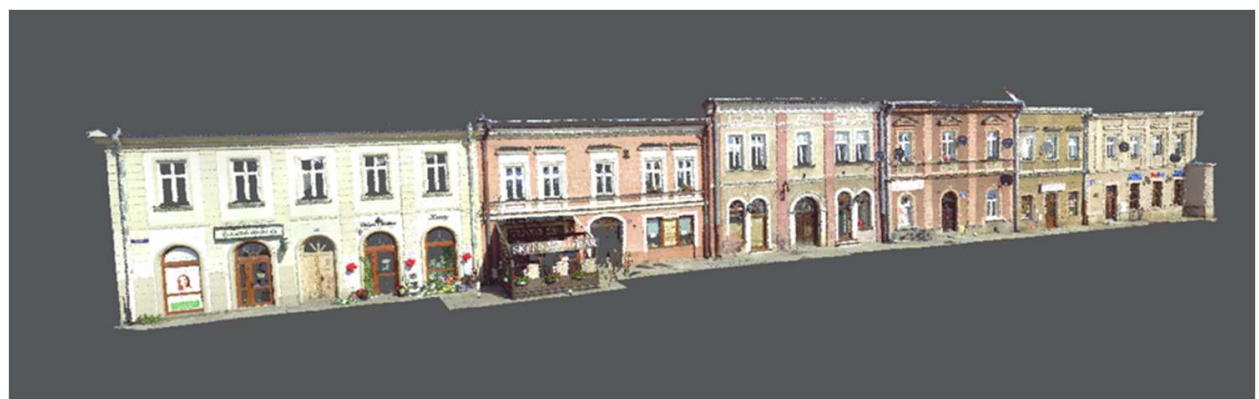

Photo 6. An example of a generated orthophoto image of the north-western frontage of the Old Market in Jarosław in Autodesk Recap 360 program;

Source: own elaboration

\section{DATA ANALYSIS AND POTENTIAL USE OF COLLECTED DATA}

Based on the TLS measurements, models of the north-western and south-eastern elevations (frontages) of the Jarosław tenements were made, and analyses of the accuracy of the measurements were carried out. Research methods and techniques recommended in architecture were used to analyse the data [24]. Accuracy analyses related to the determination of the distance measurement deviation values for selected points of the southeast elevation/spire (Table 1) were calculated using equation (1):

$$
|\Delta d k j|=\mid \text { dkkj-dskjl }
$$

where:

$|\Delta \mathrm{dkj}|$ - absolute value of deviation of distance measurement between points; $\mathrm{dkkj}$ - distance read by classic method (measuring tape);

dskj - distance obtained by terrestrial laser scanner 
APPLICATION OF TERRESTRIAL LASER SCANNING FOR THE INVENTORY OF HISTORICAL BUILDINGS ON THE EXAMPLE OF MEASURING THE ELEVATIONS OF THE BUILDINGS IN THE OLD MARKET SQUARE IN JAROSEAW

Table 1. Comparison of distances obtained using the classical method and the scanner for scans connected using reference spheres

\begin{tabular}{|c|c|c|c|}
\hline Points & $d_{k j}^{k}[\mathrm{~mm}]$ & $d_{k j}^{S}[\mathrm{~mm}]$ & $\left|\Delta d_{k j}\right|_{[\mathrm{mm}]}$ \\
\hline \multirow{8}{*}{ Edges } & 41494,654 & 41501,6 & 6,944 \\
\hline & 41498,356 & 41499,27 & 0,913 \\
\hline & 41505,752 & 41517,68 & 11,93 \\
\hline & 41502,845 & 41509,78 & 6,933 \\
\hline & 41502,426 & 41511,54 & 9,115 \\
\hline & 41502,429 & 41508,38 & 5,951 \\
\hline & 41499,194 & 41507,29 & 8,091 \\
\hline & 41502,268 & 41511,28 & 9,016 \\
\hline \multirow{8}{*}{ Plane } & 41502,169 & 41507,33 & 5,156 \\
\hline & 41499,732 & 41502,79 & 3,057 \\
\hline & 41503,138 & 41511,21 & 8,071 \\
\hline & 41503,769 & 41510,8 & 7,034 \\
\hline & 42501,687 & 42510,66 & 8,968 \\
\hline & 42595,781 & 42603,86 & 8,082 \\
\hline & 42166,164 & 42172,24 & 6,072 \\
\hline & 42473,178 & 42491,17 & 17,992 \\
\hline
\end{tabular}

The standard deviation, which was taken as a criterion to describe the measurement accuracy, for a small number of measurements was calculated from equation (2): 


$$
\sigma=\sqrt{\frac{\sum_{i=1}^{n} \Delta d_{k j}^{2}}{n-1}}
$$

where:

$\sigma$ - standard deviation;

$\mathrm{n}$ - number of measurements.

In Table 1, the measurement results obtained from the measurements with the classical method and with the laser scanner for the combined scans, as well as the length deviation expressed in millimetres are presented. Obtained calculation results concerning accuracy of measurement were grouped with respect to edges and planes (Figure 1).

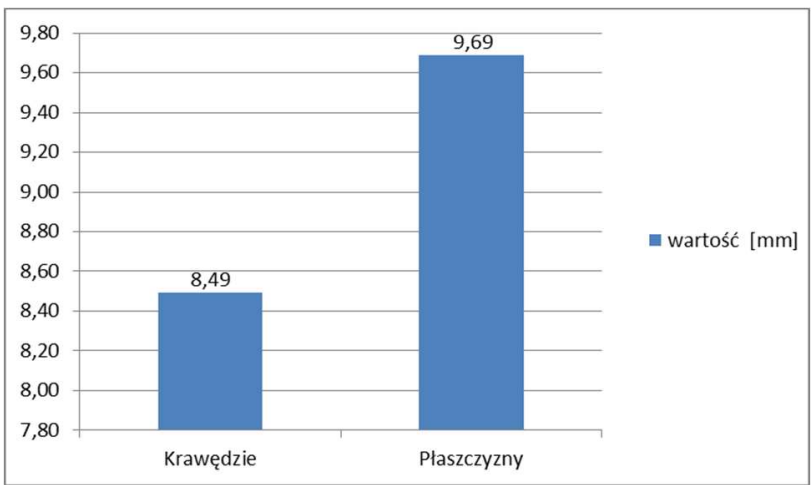

Fig. 1. Standard deviation of combined scans (reference spheres)

On the basis of the analysis of the results it can be stated that the accuracy of the performed elevation models is $8.79 \mathrm{~mm}$, which is about $1 \mathrm{~cm}$. The smallest error can be noted in the measurements for the edges $8.49 \mathrm{~mm}$, and for the planes 9.69 $\mathrm{mm}$.

The data obtained during the survey of the north-western and south-eastern frontage of the Jarosław tenement houses can be used for data preparation and further processing of the detailed point cloud in order to elaborate all visible external architectural-decorative elements of the facade. The data obtained from measurements, after supplementation, can be the basic source of information to make projections and cross-sections (longitudinal and transverse) and to build a 3D model.

The example of the performed measurements of the elevations for the buildings of the Old Market Square in Jarosław proves that the use of scanning allows to collect information related to the geometry of the surveyed walls. The resulting point cloud could also be used as a georeference for photogrammetric images, and then to read the coordinates of natural photopoints, from which calculations could 


\author{
APPLICATION OF TERRESTRIAL LASER SCANNING FOR THE INVENTORY \\ OF HISTORICAL BUILDINGS ON THE EXAMPLE OF MEASURING THE ELEVATIONS \\ OF THE BUILDINGS IN THE OLD MARKET SQUARE IN JAROSŁAW
}

be made for the photogrammetric project. The geometrically coherent measurement material collected in this way would enable the generation of detailed orthophotoplans that could be used to prepare a revitalization project for the market square tenements.

\title{
5. SUMMARY
}

Compared to other measurement tools used in the creation of architectural documentation for cultural heritage sites, the impact of modern technology over the past decades is evident and has introduced rapid evolutionary progress. Laser scanning enables measurement and data acquisition at high speed, high density and high accuracy to obtain a 3D model. TLS can successfully replace classical measurement methods and has great advantages over them. In addition, it becomes a tool that allows to optimize the number of conducted works, which in turn is associated with reduction of research costs both at the stage of data acquisition and processing. Application of this technology improves the quality of prepared architectural studies making them more attractive, and what is the most important, in many cases it is the only way to conduct a full survey of an object with a complex geometry or located in an area where classical measurements are not possible.

The potential of the data obtained using TLS creates at the moment the possibility of their versatile application not only in surveying, construction, architecture, but also in conservation and revitalization of monuments, archaeology or history. The use of this technology during the creation of architectural documentation of a historic building greatly facilitates the acquisition of comprehensive information about its actual condition in a fast, non-invasive and very precise manner. It also provides an opportunity to accurately interpret the condition of an object and present its model in a virtual space thanks to digital technology.

\section{REFERENCES}

1. Agosto, E, Ardissone, P and Bornaz, L 2005. The castle of Graines: different survey methodologies for the documentation of historical buildings. In: Proceedings of CIPA XXth International Symposium, September 26-October 1, Torino, Italy, 55-58.

2. Al-Kheder, S, Al-Shawabkeh, Y and Haala, N 2009. Developing a documentation system for desert palaces in Jordan using 3D laser scanning and digital photogrammetry. Journal of Archaeological Science 36, 537-546. 
3. Bernat, $M$ et al. 2016. Zastosowanie naziemnego skaningu laserowego i przetwarzanie danych: inwentaryzacja i inspekcja obiektów budowalnych. Przegląd technologii i przykłady zastosowań. Seria Geomatyka, Wyd. INET.PL Sp. J.: Gdańsk, Poland, 8-31.

4. Chmielewski, J, Maciejewska, A and Turek, A 2013. Możliwości ochrony tożsamości kulturowej, społecznej, przyrodniczej i urbanistycznej małego miasta In: Heffrer K, Twardzik M, (ed.) Nowoczesne infrastruktury polityki rozwoju lokalnego - zastosowanie i efekty w małych miastach. Studia Ekonomiczne: Zeszyty Naukowe Uniwersytetu Ekonomicznego w Katowicach, Wydawnictwo Uniwersytetu Ekonomicznego w Katowicach: Katowice, Poland, 253-268.

5. Deliś, P, Wilińska, M and Fryśkowska, A 2014. 3D modelling of cultural heritage objects using video technology. Biuletyn Wojskowej Akademii Technicznej 63(2), 57-69.

6. Deliś, P, Wojtkowska, M, Nerc, P, Ewiak, I and Lada, A 2016. Integration of geodata in documenting castle ruins. The International Archives of the Photogrammetry, Remote Sensing and Spatial Information Sciences, Volume XLI-B3, 2016 XXIII ISPRS Congress, 12-19 July 2016, Prague, Czech Republic.

7. Górka, A 2013. Zrównoważone formy funkcjonowania miasta i jego otoczenia (przegląd współczesnych koncepcji). Architektura Krajobrazu Studia i Prezentacje. 1-2, 36-46.

8. Haddad, N 2011. From ground surveying to 3D laser scanner: A review of techniques used for spatial documentation of historic sites. Journal of King Saud University-Engineering Sciences 23(2), 109-118.

9. Haddad, N 2007. Towards creating a dialogue between the specialized technician and non technician users of the 3D laser scanner. In: Proceedings of CIPA XXIth International Symposium. October 01-06, Athens, Greece, 350-355.

10. Haddad, $\mathrm{N}$ and Ishakat, F 2007. 3D Laser scanner and reflectorless total station: a comparative study of the slots of El-Khazneh at Petra in Jordan. In: Proceedings of CIPA XXIth International Symposium. October 01-06, Athens, Greece, 356-361.

11. Janikowski, R and Krzysztof, K, (ed.) 2009. Kultura a zrównoważony rozwój: środowisko, ład przestrzenny, dziedzictwo w świetle dokumentów UNESCO i innych organizacji międzynarodowych. Polski Komitet do Spraw UNESCO: Warszawa, Poland.

12. Kamiński, W, Bojarowski, K, Dumalski, A, Mroczkowski, K and Trystuła, J 2008. Ocena możliwości wykorzystania skanera laserowego scanstation firmy Leica w badaniu deformacji obiektów budowlanych. Czasopismo Techniczne Wydawnictwo Politechniki Krakowskiej, 105(2-Ś), 140-142. 


\section{APPLICATION OF TERRESTRIAL LASER SCANNING FOR THE INVENTORY OF HISTORICAL BUILDINGS ON THE EXAMPLE OF MEASURING THE ELEVATIONS OF THE BUILDINGS IN THE OLD MARKET SQUARE IN JAROSŁAW}

13. Kędzierski, M, Fryśkowska, A, Dąbrowski, R and Wilińska, M 2009. Naziemne skanowanie laserowe obiektów sakralnych z wykorzystaniem technologii HDS. Wiadomości Konserwatorskie 26, 670-678.

14. Kędzierski, M, Walczykowski, P and Fryśkowska A 2008. Naziemny skaning laserowy drogowych obiektów inżynierskich. Archiwum Fotogrametrii, Kartografii i Teledetekcji 18, 211-219.

15. Kędzierski, M, Walczykowski, P and Fryśkowska A 2008. Wybrane aspekty opracowania dokumentacji architektonicznej obiektów zabytkowych. Archiwum Fotogrametrii, Kartografii i Teledetekcji 18, 221-230.

16. Krasnowolski, B 2011. Z badań nad rynkami i placami w planach urbanistycznych i programach miast małopolskich, [In:] Krabath S, Piekalski J, Wachowski K. (ed.) Ulica, plac i cmentarz w publicznej przestrzeni średniowiecznej i wczesno nowożytne miasta Europy środkowej. Wratislavia Antiqua: studia z dziejów Wrocławia 13. Uniwersytet Wrocławski. Instytut Archeologii: Wrocław, Poland, 163-178.

17. Kwoczyńska, B, Litwin, U, Piech, I, Obirek, P and Śledź, J 2016. The Use of Terrestrial Laser Scanning in Surveying Historic Buildings. In: Proceedings of 2016 Baltic Geodetic Congress (Geomatics), 263-268.

18. Lerma, JL et al. 2008. Theory and Practice on Terrestrial Laser Scanning. Training Material Based on Practical Applications. Universidad Politecnica de Valencia Editorial; Valencia, Spain.

19. Leśniak, A and Górka, M 2020. Structural analysis of factors influencing the costs of facade system implementation. Applied Sciences 10, 6021.

20. Mrówczyńska, M, Bazan-Krzywoszańska, A, Skiba, M, Bazuń, D and Kwiatkowski, M 2018. Social and Infrastructural Conditioning of Lowering Energy Costs and Improving the Energy Efficiency of Buildings in the Context of the Local Energy Policy. Energies 11, 2302.

21. Mrówczyńska, M, Łączak, A, Bazan-Krzywoszańska, A and Skiba, M 2018. Improving Energy Efficiency with the Risk of Investment of Reference to Urban Development of Zielona Gora. Tehnicki Vjesnik-Technical Gazette 25, 916-922.

22. Mitka, B 2007. Usability of terrestrial laser scanners for the process of documentation and modeling of historical objects. Archiwum Fotogrametrii, Kartografii i Teledetekcji 17b, 525-534.

23. Navarro, S, Seguĭ, A, E, Portalěs, C, Lerma JL, Akasheh, T and Haddad, N 2009. Integration of TLS data and non-metric imagery to improve photo models and recording. A case study on Djin Block No. 9, Petra (Jordan). In: 
Proceedings of the 15th International Conference on Virtual Systems and Multimedia, VSMM 2009. Vienna, Austria, September 9-12, 2009.4.

24. Niezabitowska, E 2014. Metody i techniki badawcze w architekturze. Gliwice: Wydawnictwo Politechniki Śląskiej.

25. Oleniacz, G, Skrzypczak, I, Slęczka, L, Świętoń, T and Rymar, M 2017. Survey of the urban bell in the belfry of st. Trinity church in Krosno. Reports on geodesy and geoinformatics 103,38-45.

26. Piech, I, Kwoczyńska, B and Ciszewski, A 2018. Reconstruction of an architectural object. Case study: Citadel fort No. 33 "Krakus" in Krakow. E3S Web of Conferences 63, 00010.

27. Quinn, J, Smart, P and Jones C 2009. 3D city registration and enrichment. Proceedings of ISPRS COST Workshop on Quality, Scale and Analysis Aspects of City Models. Lund, Sweden.

28. Rüther, H, Mtalo, G and Mngumi E 2003. 3D modelling of heritage sites in Africa. A case study in the world heritage site of Kilwa Kisiwani, Tanzania. In: Proceedings CIPA XIXth International Symposium, September 30 October 4, Antalya, Turkey, pp.175-180.

29. Rzońca, A 2004. Contemporary methods of comprehensive inventory of monuments on the example of a parish church in Michalice; [In Polish: Współczesne metody kompleksowej inwentaryzacji zabytków na przykładzie parafialnego kościoła w Michalicach]. Archiwum Fotogrametrii, Kartografii i Teledetekcji 14, 1-8.

30. Santana Quintero, M and Van Genechten, B 2007. Three-dimensional risk mapping for anti-disaster recording of historic buildings. In: Proceedings of CIPA XXIth International Symposium. October 01-06, Athens, Greece, 325330.

31. Sikora, A 2019a. Possibilities for Creating Public Spaces in a Small Town: Case Study In: IOP Conference Series: Materials Science and Engineering 603, Section 2.

32. Sikora, A 2019b. Heritage of the Polish Central Industrial District - New Cities In: IOP Conference Series: Earth and Environmental Science 362.

33. Skrzypczak, I, Słowik, M and Buda-Ożóg, L 2017. The application of reliability analysis in engineering practice - reinforced concrete foundation. 9th International Conference on Analytical Models and New Concepts in Concrete and Masonry Structures (AMCM): Procedia Engineering, Gliwice, 193, 144-151.

34. Skrzypczak, I, Kokoszka, W, Zięba, J, Leśniak, A, Bajno, D and Bednarz, L 2020. A Proposal of a Method for Ready-Mixed Concrete Quality Assessment Based on Statistical-Fuzzy Approach. Materials 13, 5674.

35. Słowik, M, Kotynia, R, Skrzypczak, I and Kaszubska, M 2017. The application of a probabilistic method to the reliability analysis of 


\section{APPLICATION OF TERRESTRIAL LASER SCANNING FOR THE INVENTORY OF HISTORICAL BUILDINGS ON THE EXAMPLE OF MEASURING THE ELEVATIONS OF THE BUILDINGS IN THE OLD MARKET SQUARE IN JAROSŁAW}

longitudinally reinforced concrete beams. 9th International Conference on Analytical Models and New Concepts in Concrete and Masonry Structures (AMCM): Procedia Engineering, Gliwice, Poland, 193, 273-280.

36. Soudarissanane, S, Lindenbergh, R and Gorte, B 2008. Reducing the error in terrestrial laser scanning by optimizing the measurement set-up. The International Archives of the Photogrammetry, Remote Sensing and Spatial Information Sciences Vol. XXXVII(B5), 615-620.

37. Świerczyńska, E 2015. Wykorzystanie kul referencyjnych do badania metrycznego właściwości naziemnego skanera laserowego, In: Kwaśniak M (ed.) Techniki inwentaryzacji i monitoringu obiektów inżynierskich. Wydział Geodezji i Kartografii Politechniki Warszawskiej: Warszawa, Poland, 63.

38. Tobiasz, A, Markiewicz, J, Łapiński, S, Nikel, J, Kot, P and Muradov, M 2019. Review of Methods for Documentation, Management, and Sustainability of Cultural Heritage. Case Study: Museum of King Jan III's Palace at Wilanów. Sustainability 11(24), 7046.

39. Tucci, G, Algostino, F, Bonora, V and Guidi G 2003. 3D modelling of boccaccio's hometown through a multisensor survey. International Archives of the Photogrammetry, Remote Sensing and Spatial Information Sciences Vol. XXXIV-5/W10.

40. Vacca, G, Deidda, M, Dessi, A and Marras, M 2012. Laser scanner survey to cultural heritage conservation and restoration. International Archives of the Photogrammetry, Remote Sensing and Spatial Information Sciences, Volume XXXIX-B5, 2012 XXII ISPRS Congress, 25 August - 01 September 2012, Melbourne, Australia.

41. Van Genechten, B and Schueremans, L 2009. Laserscanning for heritage documentation, Wiadomości Konserwatorskie, 26, 727-737.

42. Wężyk, P 2010. Naziemny skaning laserowy. In: Okła, K (ed.) Geomatyka w Lasach Państwowych. Część I Podstawy. Centrum Informacyjne Lasów Państwowych: Warszawa, Poland, 343-355.

43. Zaczek-Peplinska, J, Osińska-Skotak, K and Gergont, K 2012. Możliwości wykorzystania zmian intensywności odbicia promienia laserowego do oceny stanu konstrukcji betonowej. In: Plichta A, Wyczałek I, (ed.) Inżynieryjne zastosowania geodezji. Wydawnictwo Politechniki Poznańskiej: Poznań, Poland. 